Relations industrielles

Industrial Relations

\title{
Trade Union Statistics
}

Volume 6, numéro 1, décembre 1950

URI : https://id.erudit.org/iderudit/1023262ar

DOI : https://doi.org/10.7202/1023262ar

Aller au sommaire du numéro

Éditeur(s)

Département des relations industrielles de l’Université Laval

ISSN

0034-379X (imprimé)

1703-8138 (numérique)

Découvrir la revue

Citer cet article

(1950). Trade Union Statistics. Relations industrielles / Industrial Relations, 6(1), 30-30. https://doi.org/10.7202/1023262ar

Tous droits réservés (C Département des relations industrielles de l’Université Laval, 1950
Ce document est protégé par la loi sur le droit d'auteur. L'utilisation des services d'Érudit (y compris la reproduction) est assujettie à sa politique d'utilisation que vous pouvez consulter en ligne.

https://apropos.erudit.org/fr/usagers/politique-dutilisation/ 


\section{Trade Union Statistics}

The annual survey of labour organization by the Department of Labour has revealed that on December 31,1949 , there exists in Canada 5.268 locals comprising 1,005,639 union members. If Newfoundland is included, some 24,000 members must be added to the total.

This million of union workers is spread out in the following manner. The strength of the Trades and Labour Congress of Canada, a group counting 2,805 locals of affiliated or directly chartered unions. amounts to 459,068 members. The American Federation of Labour includes 29 Canadian units which are directly attached to it. The latter counts 13,996 members. The Canadian Congress of Labour with 1,175 locals, has 301,729 members. The Congress of Industrial Organizations of the United States possesses 53 Canadian locals which are attached to it and comprising 27,475 members. The Canadian and Catholic Confederation of Labour has 424 locals covering 80,089 members. The International Railway Brotherhoods (independent) have 382 locals and 41,363 members. The Canadian Federation of Labour has 3,872 members spread out among 7 locals. The National Council of Canadian Labour counts 3,451 members in 17 locals. There are also a certain number of unaffiliated National and International Unions, possessing 255 locals and 57,923 members. Finally, local unaffiliated Unions count 61 locals and 16,673 members. '

(1) Source of information: News Release of the Federal Department of Labour, September 20, 1950.

\section{LETTER TO THE EDITOR}

\section{PROVINCE OF MANITOBA DEIPARTMENT OF LABOR}

November 3, 1950.

Gerard Tremblay, Esq.,

Director,

Department of Industrial Relations,

University of Laval,

Quebec.

Dear Mr. Tremblay,

I am very glad to have this opportunity to write to you, on your capacity of Director of the Industrial Relations Repartment, upon receipt of your circular letter of October 20th.

I read the Industrial Relations Bulletin almost religiously. feeling that its approach to problems which affect the industrial relations of Canada is both novel and constructive.

I may say that I have recommended the Bulletin to Manitoba lawyers and to administrators of labor legislation, as being calculated to give them invaluable insight into the problems with which they are faced.

I am very interested, therefore, in your announcement that the new Review will appear every three months and will contain sixty pages of original material, constituting a fresh and thorough study of a subject directly connected with industrial relations.

The bilingual feature of your Bulletin has a particular interest to me, as I am able to keep my French from getting too rusty, nevertheless am able when stuck by a particular word to refer to the English version.

I would like to congratulate you upon the high standard which the Bulletin has continuously maintained, and to wish you every success in the new venture which will see the Bulletin become a Quarterly, in a somewhat more portentious way.

With best personal wishes, I am,

Yours sincerely,

W. Elliot Wilson, Deputy Minister of Labor.
A man's ability to be a pioneer of progress, that is, to understand what civilization is and to work for it, depends on his being $a$ thinker and on his being free. He must be the former if he is to be capable of comprehending his ideals and putting them into shape. He must be free in order to be in a position to launch his ideals out into the general life... Materials and spiritual freedom are closely bound up with one another. Civilization presupposes free men, for only by free men can it be thought out and brought to realization.

Albert Schweitzer
It is better to suffer wrong than to do it, and happier to be sometimes cheated than not to trust.

$$
\text { * } \quad \text { Samuel Johnson }
$$

Greatness is a two-faced coin - and its reverse is humility.

$$
\text { * } \text { Marguerite Steen }
$$

Il we command our wealth, we shall be rich and free; if our wealth commands us, we are poor indeed.

Edmund Burke 